\title{
Self-assessment of managerial knowledge and skills of medical doctors in primary health care
}

\author{
Aida Pilav ${ }^{1,2 *}$, Enes Šačić ${ }^{3}$ \\ ${ }^{1}$ University Clinical Centre Sarajevo, Institute for Clinical Research, Sarajevo, Bosnia and Herzegovina, ${ }^{2}$ Faculty of Health \\ Studies, University of Sarajevo, Sarajevo, Bosnia and Herzegovina, ${ }^{3}$ Department of Edpidemiology, Medical Center of the \\ Canton Sarajevo, Sarajevo, Bosnia and Herzegovina, Medical Center of the Canton Sarajevo, Family Medicine Department, \\ Sarajevo, Bosnia and Herzegovina
}

\begin{abstract}
Introduction: The aim of this paper was to evaluate the managerial knowledge and skills of mid-level managers - medical doctors in Medical center of the Canton Sarajevo.

Methods: A cross-sectional study of the mid-level managers in the Medical center of the Canton Sarajevo was conducted using an originally developed questionnaire for self-assessment of managerial knowledge and skills. The respondents answered each of the questions using a 5-point Likert scale. Apart from the quantitative section, the respondents could present their observations concerning the educational needs in the health care system.
\end{abstract}

Results: Almost $40 \%$ of the respondents said that the process of assessing health care needs is not conducted. No statistical significance was observed in the responses according to the length of service in a managerial position. In total, $41 \%$ of the respondents were not sure whether a plan exists, even though the development of these plans should be a principal managerial responsibility in the quality management. Managers who were longer in the position reported no plans for corrective actions. This result was in contrast with the answers obtained from the managers who were in the position for a shorter period. In addition, $91 \%$ of the respondents said that they regularly discuss problems with their employees.

Conclusions: Self- assessment and assessment of managerial competencies should be regular activities in a health care organization, in order to monitor the knowledge and skills, as well as to make the development plans. The results of this study could serve as the basis for planning and developing the health management education in the Canton Sarajevo.

Keywords: health management; primary health care; health needs assessment

\footnotetext{
*Corresponding author: Aida Pilav, MD PhD, Institute for Clinical Research, University Clinical Centre Sarajevo, Bolnička 25, 71000 Sarajevo, Bosnia and Herzegovina, Phone: +387 33298893

E-mail: idanap@bih.net.ba
}

Submitted: 16 January 2016 / Accepted: 07 March 2016

DOI: http://dx.doi.org/10.17532/jhsci.2016.325

UNIVERSITY OF SARAJEVO

FACULTY OF HEALTH STUDIES

\section{INTRODUCTION}

According to the WHO's Declaration of AlmaAta (1978) primary health care (PHC) is defined as essential health care and has the most significant role in protecting citizens' health. Numerous studies have demonstrated that health systems that 
rely on PHC have improved fairness, ensure more adequate use of the services, and improve patients' satisfaction (1).

The ongoing health care reforms in Bosnia and Herzegovina (BIH) are focused on strengthening the primary health care. Primary health care teams consist of doctors of family medicine and nurses. According to the reform orientation in the Federation of Bosnia and Herzegovina (FBIH), these practitioners need to be connected with other services in the primary health care, local communities, municipal governments, and public health (2). Better health care should be an imperative for a health system. In general, improved health status of the population is a basic indicator of the quality of a health care system.

Medical center of the Canton Sarajevo is a PHC institution whose mission is to promote effective, fair, accessible, integrated, and cost-efficient health care programs and services in order to meet the needs of the Sarajevo canton citizens. The institution's vision is to use PHC to build an environment that will foster work excellence, professional development of the employees, team work and human relations. The main focus of the institution are patients, and the final objective are the preservation of citizens' health and the progress of the entire community.

Measuring knowledge and skills of health care workers on managerial positions of all levels is essential in order to identify the needs and possibilities for further development and improvement of knowhow and skills. At the same time, self-assessment of the managerial knowledge and skills of health care workers working in managerial positions at $\mathrm{PHC}$ institutions has to include a personal development plan of every respondent (2-4).

Self-assessment of managerial knowledge and skills was conducted among mid-level managers in the Medical center of the Canton Sarajevo in order to define the requirements for additional education, as well as to support achieving the mission and vision of the health care institution.

\section{METHODS}

A cross-sectional study of mid-level managers in the Medical center of the Canton Sarajevo was conducted in the period between September, 2014 and October, 2014 using an originally developed questionnaire for self-assessment of managerial knowledge and skills. The questionnaire has been developed analyzing the existing literature on managerial competencies of doctors of medicine in primary health care (3-5). After the piloting and validation, the final version of the questionnaire consisted of three sections, including: assessment of service provision in a local community, personal management, and leadership skills. The respondents answered each of the questions of the three sections using a 5-point Likert scale. Aside from the quantitative part, the respondents could present their observations concerning the need for improvement using the method "learning by doing".

The principle variables of the study were the respondents classified by the gender (male, female), age (36-45 years, 46-55 years, >56 years) and length of managerial experience in the current position ( $<1$ years, $1-5$ years, 5-7 years, $7-10$ years, $>10$ years). The initial study population included 70 mid-level managers working at the Sarajevo Health Center. The questionnaire was distributed to the participants' work addresses with a cover letter including main information about the study.

The study was conducted in accordance with the ethical guidelines for medical research and was approved by the Ethic Committee of the Health center of the Canton Sarajevo.

\section{Statistical analysis}

Descriptive statistics was used to present the data. The Chi-square test with $95 \%$ confidence level was used to test the differences between the groups. Data were analyzed using SPSS for Windows version 20.0.

\section{RESULTS}

Out of the 70 managers in the Sarajevo Health Center, 46 participated in the survey $(65 \%$ response rate). Among them, 7 were the directors of the organizational units and 39 were the heads of the services. In total, $85 \%$ of the respondents were females, and $15 \%$ were males. In terms of the age groups, $50 \%$ of the respondents were in the age group 56 years 
and above, and $41 \%$ respondents were in the age group 46 to 55 years (Table 1).

The average age of the respondents was 53.8 years. Only $9 \%$ of the respondents in the managerial positions were in the age group 36 to 44 years. In terms of the length of service in a managerial position, $32 \%$ of the respondents spent 1 to 5 years in a managerial position, and $13 \%$ spent 7 to 10 years in the position (Figure 1). In total, $24 \%$ of the respondents completed a certified health management course.

The respondents answered a set of questions on the modes of assessing the needs for health care, as well as on the mode of service provision. Almost

TABLE 1. Demographic profile of surveyed managers medical doctors in the primary health care

\begin{tabular}{lccc}
\hline Age groups & \multicolumn{2}{c}{ Sex } & Total \\
\cline { 2 - 3 } & Male N (\%) & Female N (\%) & N (\%) \\
\hline 36 to 45 years & $0(0)$ & $4(10.3)$ & $4(8.7)$ \\
46 to 55 years & $2(28.6)$ & $17(43.6)$ & $19(41.3)$ \\
56 and older & $5(71.4)$ & $18(46.2)$ & $23(50)$ \\
Total & $7(100)$ & $39(100)$ & $46(100)$ \\
\hline
\end{tabular}

$40 \%$ of the respondents said that the process of assessing health care needs is not conducted. There is no statistical significance in the responses according to the length of service in a managerial position. Almost $35 \%$ of the respondents said that they are not involved in the planning of the health care needs. Six percent of the respondents did not provide an answer to this question. There is no statistical significance in the assessing provision of services in the local community with respect to

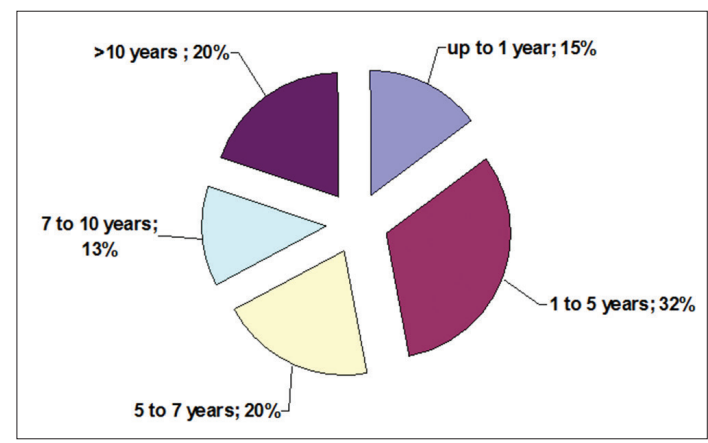

FIGURE 1. Length of service in a managerial position.

TABLE 2. Assessment of the knowledge and attitude towards the provision of services in local community between the managers of different length of managerial experience

\begin{tabular}{|c|c|c|c|c|c|c|c|}
\hline & $\begin{array}{c}\text { I fully } \\
\text { agree (\%) }\end{array}$ & $\begin{array}{c}\text { Agree } \\
(\%)\end{array}$ & $\begin{array}{l}\text { I neither agree } \\
\text { nor disagree (\%) }\end{array}$ & $\begin{array}{l}\text { Disagree } \\
(\%)\end{array}$ & $\begin{array}{c}\text { I fully } \\
\text { diasgree (\%) }\end{array}$ & $\begin{array}{l}\mathrm{N} / \mathrm{a} \\
(\%)\end{array}$ & $p$ value* \\
\hline $\begin{array}{l}\text { Health care services that I provide focus on } \\
\text { principal health problems in the local community/ } \\
\text { municipality in which I work }\end{array}$ & 37.0 & 45.7 & 8.7 & 6.5 & 2.2 & 0 & $p>0.05$ \\
\hline $\begin{array}{l}\text { I assess health care needs of local community/ } \\
\text { municipality in which I work together with the } \\
\text { representatives of local community/municipality } \\
\text { in which I work }\end{array}$ & 13.0 & 30.4 & 15.2 & 30.4 & 8.7 & 2.2 & $p>0.05$ \\
\hline $\begin{array}{l}\text { I am involved in the process of planning health } \\
\text { needs and health care needs of the local } \\
\text { community/municipality in which I work }\end{array}$ & 19.6 & 32.6 & 6.5 & 26.1 & 8.7 & 6.5 & $p>0.05$ \\
\hline $\begin{array}{l}\text { Health care services I provide are designed as an } \\
\text { integral part of a referral system in the Canton* }\end{array}$ & 23.9 & 39.1 & 19.6 & 8.7 & 4.3 & 4.3 & $p>0.05$ \\
\hline $\begin{array}{l}\text { Preventive services are equally represented as } \\
\text { disease treatment }\end{array}$ & 15.2 & 28.3 & 4.3 & 37.0 & 8.7 & 6.5 & $p>0.05$ \\
\hline $\begin{array}{l}\text { Health care services are directed towards all } \\
\text { social and economic levels of population in the } \\
\text { local community in which I work }\end{array}$ & 54.3 & 32.6 & 4.3 & 2.2 & 2.2 & 4.4 & $p>0.05$ \\
\hline $\begin{array}{l}\text { Know-how and skills of health care professionals } \\
\text { are at a satisfactory level }\end{array}$ & 8.7 & 63.0 & 19.6 & 4.3 & 2.2 & 2.2 & $p>0.05$ \\
\hline $\begin{array}{l}\text { If an appropriate problems is identified, there is a } \\
\text { clear plan for corrective measures }\end{array}$ & 8.7 & 32.6 & 41.3 & 10.9 & 4.3 & 2.2 & $p<0.05$ \\
\hline
\end{tabular}


the length of managerial service (Table 2). Almost $50 \%$ of the respondents said that preventive services are not equally represented as disease treatments (Table 2).

A plan for corrective actions is essential in the practice of quality management in the health care. The responses of the PHC managers to this question were different. In total, $41 \%$ of the respondents were not sure whether a plan exists, even though the development of these plans should be a principal managerial responsibility in the quality management. Statistically significant difference $(\mathrm{p}<0.05)$ was observed in the answers according to the length of service in a managerial position. The managers who were longer in the position reported no plans for corrective actions, unlike the managers who were in the position for a shorter period of time who reported that if an appropriate problems is identified, there is a clear plan for corrective measures.

\section{Personal management}

Clear job duties have to be described in order to manage activities. Considering the formal process of work and the hierarchical organization in health care institutions, $88 \%$ of the respondents confirmed a clear description of the job duties. There was no significant statistical difference in the responses according to the length of service in a managerial position. A clear understanding of a manager's level of responsibility was observed, with $98 \%$ of the respondents understanding the level of their own responsibility (Table 3 ).

Most of the respondents (36\%) said that they are not certain whether there is a clear strategic plan for the institution, while $28 \%$ of them completely agreed that there is a clear strategic plan for the institution Ninety-one percent of the respondents said that they regularly discuss problems with their employees, indicating that making managerial decisions is

TABLE 3. Assessment of the personal managerial attitude and skills between the managers of different length of managerial experience

\begin{tabular}{|c|c|c|c|c|c|c|}
\hline & $\begin{array}{c}\text { I fully } \\
\text { agree (\%) }\end{array}$ & $\begin{array}{c}\text { Agree } \\
(\%)\end{array}$ & $\begin{array}{l}\text { I neither agree } \\
\text { nor disagree (\%) }\end{array}$ & $\begin{array}{l}\text { Disagree } \\
(\%)\end{array}$ & $\begin{array}{c}\text { I fully } \\
\text { diasgree (\%) }\end{array}$ & $p$ value \\
\hline $\begin{array}{l}\text { I have a clear job description that gives a } \\
\text { detailed description of my everyday tasks }\end{array}$ & 43.5 & 45.7 & 6.5 & 2.2 & 2.2 & $p>0.05$ \\
\hline $\begin{array}{l}\text { My education and experience are fully } \\
\text { appropriate for my current obligations/tasks }\end{array}$ & 58.7 & 34.8 & 6.5 & 0 & 0 & $p>0.05$ \\
\hline $\begin{array}{l}\text { I clearly understand type of decisions that I can } \\
\text { independently make }\end{array}$ & 47.8 & 45.7 & 4.3 & 2.2 & 0 & $p>0.05$ \\
\hline $\begin{array}{l}\text { There is a clear Strategic plan of the health care } \\
\text { institution }\end{array}$ & 28.3 & 31.6 & 35.8 & 2.2 & 2.2 & $p>0.05$ \\
\hline $\begin{array}{l}\text { I prepare written operative plans with set goals, } \\
\text { execution deadlines and indicators to monitor } \\
\text { the goals }\end{array}$ & 29.3 & 33.8 & 19.6 & 15.2 & 2.1 & $p>0.05$ \\
\hline $\begin{array}{l}\text { I regularly discuss problems with my employees } \\
\text { before I make a managerial decision }\end{array}$ & 39.1 & 52.2 & 6.5 & 2.2 & 0 & $p>0.05$ \\
\hline $\begin{array}{l}\text { I do not wait long to have the decisions approved } \\
\text { when needed }\end{array}$ & 30.4 & 47.8 & 13.0 & 8.7 & 0 & $p>0.05$ \\
\hline I regularly discuss problems with my superior & 43.5 & 41.3 & 13.0 & 2.2 & 0 & $p>0.05$ \\
\hline $\begin{array}{l}\text { I have enough resources to improve work } \\
\text { efficiency at my disposal }\end{array}$ & 10.9 & 30.4 & 23.9 & 28.3 & 6.5 & $p>0.05$ \\
\hline $\begin{array}{l}\text { I have enough opportunities to promote my } \\
\text { managerial capabilities }\end{array}$ & 11.7 & 26.3 & 35.8 & 26.2 & 0 & $p>0.05$ \\
\hline $\begin{array}{l}\text { I have enough resources to complete every task } \\
\text { at my disposal }\end{array}$ & 8.4 & 32.6 & 28.3 & 23.9 & 6.5 & $p>0.05$ \\
\hline I have enough time to complete every task & 2.2 & 37.8 & 17.4 & 34.8 & 8.7 & $p>0.05$ \\
\hline There is regular evaluation of staff's performance & 13.0 & 43.5 & 23.9 & 15.2 & 4.3 & $p>0.05$ \\
\hline
\end{tabular}

${ }^{*}$ Comparison of groups based on length of managerial experience: $<1$ years, $1-5$ years, 5-7 years, $7-10$ years, $>10$ years 
TABLE 4. Assessment of the leadership skills between the managers of different length of managerial experience

\begin{tabular}{|c|c|c|c|c|c|c|}
\hline & $\begin{array}{l}\text { I fully agree } \\
(\%)\end{array}$ & $\begin{array}{c}\text { Agree } \\
(\%)\end{array}$ & $\begin{array}{l}\text { I neither agree } \\
\text { nor disagree( }(\%)\end{array}$ & $\begin{array}{c}\text { Disagree } \\
(\%)\end{array}$ & $\begin{array}{l}\text { I fully diasgree } \\
(\%)\end{array}$ & $p$ value $^{*}$ \\
\hline Manager enjoys being respected by his/her employees & 31.4 & 54.2 & 14.4 & 0 & 0 & $p>0.05$ \\
\hline $\begin{array}{l}\text { Manager should set a good example to young } \\
\text { colleagues/employees }\end{array}$ & 63.0 & 34.8 & 0 & 2.2 & 0 & $p>0.05$ \\
\hline $\begin{array}{l}\text { Manager should understand all needs of the } \\
\text { employees and should treat them individually }\end{array}$ & 56.5 & 38.0 & 6.5 & 0 & 0 & $p>0.05$ \\
\hline $\begin{array}{l}\text { Solving the personal needs of employees has to be } \\
\text { consistent and fair }\end{array}$ & 48.7 & 51.3 & 0 & 0 & 0 & $p>0.05$ \\
\hline $\begin{array}{l}\text { Manager should commend tasks that were correctly } \\
\text { executed and should put in place a fair reward policy }\end{array}$ & 71.7 & 23.9 & 4.4 & 0 & 0 & $p>0.05$ \\
\hline $\begin{array}{l}\text { If necessary, the manager should fairly discipline the } \\
\text { employees }\end{array}$ & 61.9 & 38.1 & 0 & 0 & 0 & $p>0.05$ \\
\hline $\begin{array}{l}\text { Manager should take care of employees' professional } \\
\text { advancement }\end{array}$ & 58.5 & 39.3 & 2.2 & 0 & 0 & $p>0.05$ \\
\hline
\end{tabular}

${ }^{*}$ Comparison of groups based on length of managerial experience: $<1$ years, $1-5$ years, 5-7 years, 7-10 years, $>10$ years

a participatory process. Seventy-eight percent of the respondents said that getting an approval from the higher level is moderately quick. Furthermore, $84 \%$ of the respondents confirmed that regular discussions are held with the managers (Table 4). Twentysix percent of the respondents found that they do not have enough opportunities to express their management capabilities, and $36 \%$ of the respondents were not certain whether there are enough opportunities. These results indicate the need for continuous education/training to understand managerial functions and to recognize the opportunities to apply the skills.

Almost $56 \%$ of the respondents said that there is regular evaluation of the staff.

\section{Leadership skills}

The respondents expressed a very good attitude towards the significance of the leadership skills. In $72 \%$ of the cases, the respondents found that a manager should commend all tasks that were correctly performed and that he/she should put in place a reward policy. This indicates a very good understanding of employees' motivation, which is a necessary managerial skill in building the leadership.

The statements concerning the leadership were well assessed by the respondents, and represent a basis for further improvement of these skills by the managers (Table 4).
TABLE 5. Rank list of specific managerial skills that should be developed and improved between managers - medical doctors in the primary health care
1. Attitude towards employees
2. Evaluation
3. Communication skills
4. Introspection
5. Participatory approach in decision making process
6. Independent decision making
7. Building relations
8. Public appearances
9. Skills to motivate employees
10. Assertiveness

The respondents were asked to give their observations about the needs for the improvement and development of the leadership skills. Mid-level managers found that their skills have to be improved in several fields (Table 5).

\section{DISCUSSION}

In order to respond to all the needs in provision of health care, one has to define competencies, both professional and managerial ones. Evidence based management is necessary in the modern organization of health care institutions $(5,6)$.

Heath care system should respond to new citizens' needs, be efficient, accessible, fair and sustainable, as 
well as to have a good effect on health. Health care providers must have managerial skills and knowledge in order to operate in a very complex environment of the health care system (7).

The main goal of this study was to observe the level of managerial knowledge and skills that are necessary for efficient work in the Health Center, especially in contact with the local community.

The main limitation of our study is the small sample size for the general interpretation of the results. Further research could be performed in other health centers in order to make comparisons.

Different levels of managers in health care require different competencies (8-10). Regular self-assessment and assessment of managerial competencies of managers should be a constant activity in a health care organization in order to monitor the knowledge and skills, as well as the development plans. These results could serve as a basis for planning and developing continuous health management education in Canton Sarajevo. At the same time, the effects of the continuous education should be monitored, and the improvement of the health outcomes can be expected $(11,12)$. Positive effects of formal training of health care managers on management in health care confirm the need for continuous investment in the future education and training.

Health care workers in PHC, especially the managers, should have managerial planning skills that are based on health needs assessment. In general, health needs assessment is a systematic professional approach that improves citizens' health.

Numerous studies have concluded that leadership, strategic planning, problem solving and communication were critical competencies for the performance improvement, either at the individual or organizational level. Continuous improvement in these areas can result in the optimization of health care service resources and in the improved overall health quality (13-19).

Almost half of the respondents in our survey said that they do not assess health needs, and that this knowledge and skills have to be operationalized and more developed in order to improve the quality of the health care.

Managers, who have served in this position for a very long time, reported no plans for corrective actions, unlike the managers who have performed this job for a shorter period. This implies that the managers, who have been performing this job for a shorter period, are more motivated, and this advantage should be utilized to introduce an obligatory participation in certified health care management courses.

The respondents assessed the statements about the leadership very well and this result represents a basis for further development of these skills by the managers.

In general, the results of this study can be used as a foundation to develop training initiatives, as well as a starting point of debates and discussions on development of control mechanisms aimed to improve the work in the PHC.

Besides the above-listed measures, managerial skills and competencies in the PHC have to be continuously strengthened in the forthcoming period to improve the efficiency (20). In addition, better investments should be made to improve the management development for health systems.

\section{CONFLICT OF INTERESTS}

The authors declare no conflict of interest.

\section{REFERENCES}

1. Health 21. An introduction to the health for all policy framework for the WHO European Region, Copenhagen: World Health Organizatuon, Regional Office for Europe, 1998. (European Health for All Series; no. 5).

2. Strategic plan for health sector in the Federation of Bosnia and Herzegovina, Federal Ministry of Health, 2006.

3. Health 21-Health for all in the 21.Century. WHO Regional Office for Europe. Copenhagen 1999.

4. Stefl ME. Core competence for all health care manager: the healthcare leadership alliance model. Journal of healthcare management. 2008; 56(6):360-374.

5. Rotem A, Fay J. Self-assesment for managers of health care: How Can I be Better manager? WHO, Geneva 1987.

6. Williams SJ. What skills do physician leaders need now and in the future?The Physician Executive Leadership. 2001;27:46-8.

7. Roberts MJ, Hsiao W, Berman P, Reich MR. Getting Health Reform Right. EDI, World Bank Group. World Bank Flagship Course on Health Sector Reform and Sustainable Financing, Washington DC, USA, 2001.

8. Gene Badia J, Jodar sola G, Peguero Rodriguez E. et al. The EFQM excellence model is useful for primary health care teams. Family Practice. 2001;18(4):407-409.

http://dx.doi.org/10.1093/fampra/18.4.407.

9. Leggat G.S. Effective healthcare teams require effective team members: defining teamwork competencies. BMC Health Services Research 2007; 7:17. 
http://dx.doi.org/10.1186/1472-6963-7-17.

10. Robbins CJ, Bradley EH, Spicer M: Developing leadership in health care administration: a competency assessment tool. Journal of Healthcare Management 2001;46(3):188-202.

11. Lawson JS, Rotem A, Bates PW: From Clinician to Manager: An Introduction to Hospital and Health Services Management. Sydney, McGraw-Hill Book Company; 1996.

12. Santrić Milicevic M, Bjegovic-Mikanovic, Terzic-Supic Z, Vasic V. Competencies gap of management teams in primary health care. European Journal of Public Health 2010;Vol. 21, No. 2, 247-253. http://dx.doi.org/10.1093/eurpub/ckq010.

13. Slipčević $O$, Mašić I. Management Knowledge and Skills Required in the Health Care System of the Federation Bosnia and Herzegovina. Mater Sociomed. 2012; 24(2): 106-111.

http://dx.doi.org/10.5455/msm.2012.24.106-111.
14. Kovner, A. R. The Future of Health Care Management Education: An Evidence- Based Approach, Journal of Health Administration Education. 2001; (Special Issue) 107-116.

15. Pickin C, Selwyn S.Leger. Assesing Health Need using Lyfe Cycle Framework. Open University Press 1997.

16. Wright J. Health Needs Assesment in Practice. BMJ Books. 1998.

17. Harris EM. Accessing Community development research methodologies. Canadian Journal of Public Health, 1992;83(Suppl. 1):562-566.

18. Williams SJ. What skills do physician leaders need now and in the future? The Physician Executive Leadership. 2001. 27:46-8.

19. Davies, S. Health service management education: why and what? J Health Organisation Management. 2006;20:325-34.

http://dx.doi.org/10.1108/14777260610680122.

20. Griffith JR, Warden GL, Neighbors K, et al. A new approach to assessing skill needs of senior managers. J Health Adm Educ 2002;20:75-98. 